\title{
Competitive Dynamics of Peruvian Grapes in the United States and the Netherlands Markets
}

\author{
Meredyth Ernestina Leslye Lazo Calanche ${ }^{1}$, Diana Vanessa Coca González ${ }^{1}$, Andrea Mariana Carhuaz Casafranca ${ }^{1}$, \\ Pedro Bernabe Venegas Rodriguez ${ }^{1} \&$ Nivardo Alonzo Santillán Zapata ${ }^{1}$ \\ ${ }^{1}$ Universidad Continental, Peru \\ Correspondence: Meredyth Ernestina Leslye Lazo Calanche, Universidad Continental, Peru. E-mail: \\ 77563754@ continental.edu.pe
}

Received: October 5, 2020

Accepted: December 15, 2020

Online Published: December 25, 2020

doi:10.5430/rwe.v11n6p348

URL: https://doi.org/10.5430/rwe.v11n6p348

\begin{abstract}
The growth of Peruvian fresh grapes exports encouraged the study of its competitive dynamics in the period 2010-2017. The two main world importers of the product, i.e. the United States and Netherlands were analyzed. The Relative Trade Balance, Tradability indices with the sub-indicators: Export Openness Degree and Import Penetration Degree, Symmetric Comparative Advantage and the Market Insertion Matrix, interlacing Positioning and Efficiency, were estimated. The research found that Peru and South Africa were fresh grapes competitive producers in both markets among 12 evaluated countries.
\end{abstract}

Keywords: competitiveness index, competitive dynamic, international markets

\section{Introduction}

Peru has amazing agricultural conditions. The Peruvian north and south coasts are fertile areas that contribute to the development of grape production, especially from November to March. Moreover, in such period of the year the global grape supply falls. In consequence, Peruvian grapes become the main figure in agro-exports (Moreyra, 2019). From 2000 to 2018, Peruvian grape production grew from 107,000 to 639,000 tons (MINAGRI-SIEA, n.d. in Moreyra, 2019); also, in average the Peruvian grape production was 477,183 tons (Food and Agriculture Organization of the United Nations-Statistics Division [FAOSTAT], 2019a)

The described growth can be attributed to the opening to new markets due to the signing of trade agreements with the United States, the European Union and China (Moreyra, 2019). Also, the Foreign Trade Center [CCEX] and the Lima Chamber of Commerce [CCL] identified nine markets to which Peru previously did not sell, thus promoting a greater production of 658,000 tons until August 2019, then allowing the country to expand its sells to new international markets (Lima Chamber of Commerce, 2019 ). In consequence, the grape became the second most exported Peruvian agricultural product [8.7\% of participation] achieving US\$ 166 million in sales in 2019 (Sociedad de Comercio Exterior del Perú - [COMEX], 2019).

In 2018, grape exports grew 25.8\% allowing Peru to be one of the most important grape suppliers just behind Chile and the United States (Ministerio de Comercio Exterior y Turismo - [MINCETUR], 2019). Therefore, the Peruvian annual sales, in the period 2010-2019, were US\$ 329'570,226.25 (Superintendencia Nacional de Administración Tributaria - [SUNAT], 2019).

Among grape importer countries, the United States leads the ranking with 594,877 imported tons valued at US \$1,720,208; while the Netherlands stands in second place with 385,552 imported tons valued in US\$ 900,591. Peruvian grape participation in such countries was of $42.5 \%$ and $11.6 \%$ respectively (Food and Agriculture Organization of the United Nations-Statistics Division [FAOSTAT], 2019c; ITC - TRADE MAP, 2019). Although there is a continuous increasing participation of Peruvian grapes in the international markets (as shown in figure 1), it cannot be overlooked other countries competitiveness have been both favorable and unfavorable. Therefore, it forces to analyze the level of competitiveness of Peruvian grape compared with the other suppliers in the American and Dutch markets. Hence, competitiveness will be studied by analyzing the production volume, supplying capacity for both domestic and international markets, exported value growth rate, as well as the variation of participation in world exports. 


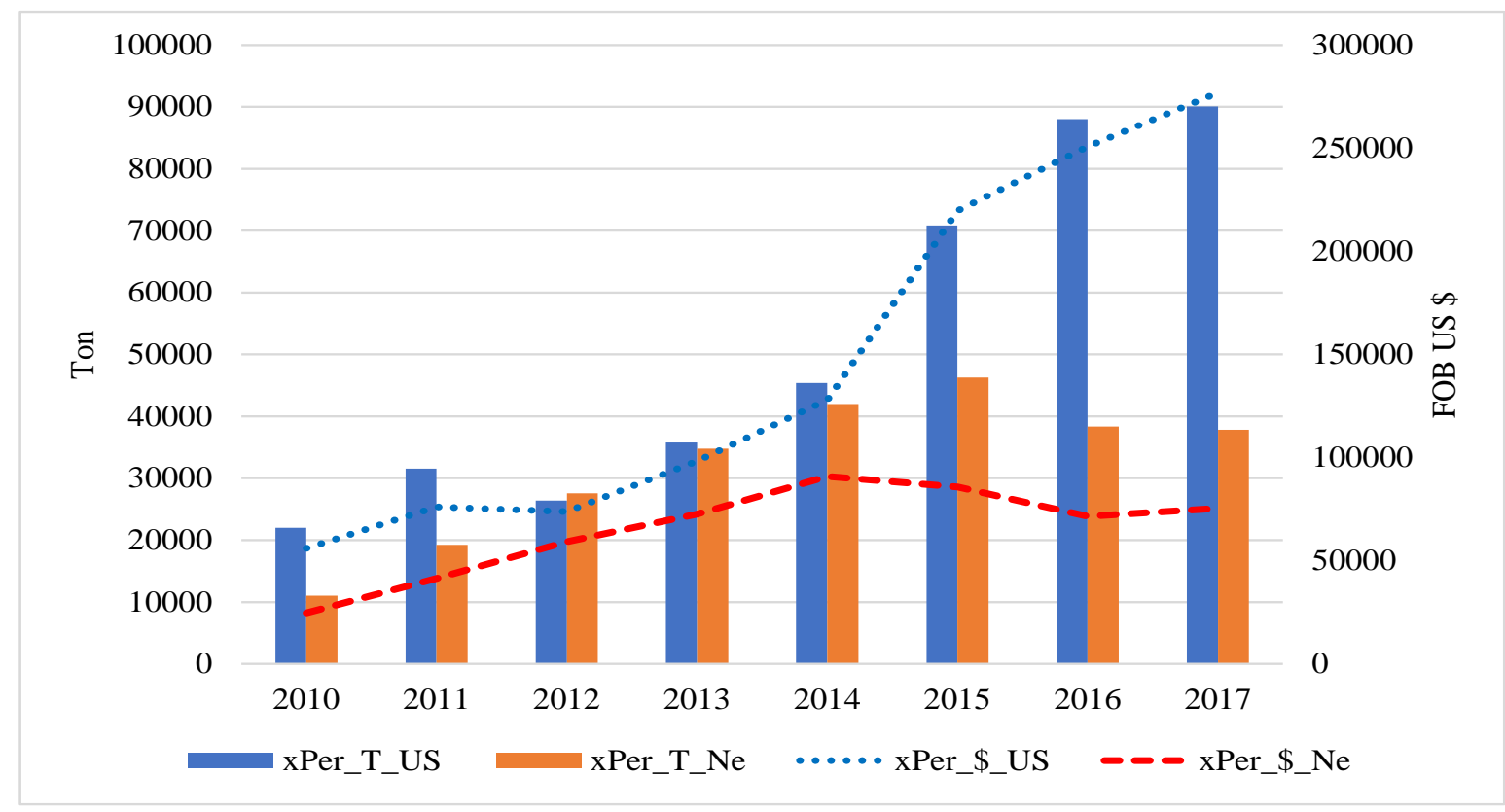

Figure 1. Peruvian exports [expressed in volume and value] to the United States and Netherlands in the period 2010 $-2017$

\subsection{Research Background}

International trade competitiveness analysis has been previously studied. Valencia and Duana (2019) employed export quotas to analyze competitiveness through the Index of Revealed Comparative Advantage [RCA], Exports Comparative Advantage [ECA], and Constant Market Share [CMS]. For one hand, it concluded that Mexico was not competitive in the grape trade despite being one of the main food suppliers to the United States. On the other hand, it was found that Peru had a better position as an important supplier of grapes by increasing its exports and improving national competitiveness. Pat et al. (2016), carried out a study with the purpose of analyzing the competitiveness of the international strawberry trade in Mexico by using competitiveness indicators such as (a) Relative Trade Balance [RTB], (b) Tradability [T], and (c) the Commercial Dependency Coefficient [CDC]. Period analyzed was 1994-2010. The study concluded that that the product was competitive both in the domestic and foreign market.

Gómez (2017) analyzed the relationship between a change in technological intensity and exports in the Association of Southeast Asian Nations. It analyzed (a ) quality, (b) competitiveness, through RTB and RCA, and (c) economic growth. The study found that in order to achieve an incremental economic growth rate, exports should aim to pass from exporting products with little value to medium and high technology products.

Stellian and Danna-Buitrago (2017) analyzed the impact of free trade in Colombia. RCA was calculated by employing the United States market as the target. Sixty groups of agricultural products were analyzed. The study concluded that most of them do not give any comparative advantage; then it is recommended to strengthen competitiveness. Fabrini Diniz (2017) studied the Symmetric Comparative Advantage [SCA] index of the main Brazilian agricultural products. Data was collected from the Food and Agriculture Organization of the United States [FAO]; as well as the Ministry of Industry, Development and Foreign Trade of Brazil for the period 2003- 2014. The study showed the existence of a positive Comparative Advantage for (a) soybeans, (b) sugar, (c) orange juice, and (d) chicken meat; while a negative one was identified in products such as (a) staple foods and (b) prepared foods. Kim (2019), analyzed the competitiveness of the Indian textile sector in the United States market in the period 1991-2017. Indicators such as (a) Revealed Comparative Advantage [RCA], (b) Comparative Market Advantage [CMA], and (c) Comparative Advantage by Country $[\mathrm{CAC}]$ were employed. The research found that India had a comparative advantage in the period studied.

Jambor, Timea, and Koroshegyi (2017) collected data of the world cocoa trade in the period 1992-2015 for testing the stability of the RCA index. The study identified determinants such as the production volume, the variety, and logistical factor. Moreover, the research found that the world cocoa trade was concentrated mainly in the Ivory Coast, 
Ghana and Indonesia. Camino, Andrade, and Pésantez (2016), aimed to analyze the insertion of Equatorian bananas, cocoa, and flowers by studying the market positioning and efficiency indices. The period studies lasted from 2010 to 2014. The research concluded that (a) banana had lost efficiency in the international market due to the decrease of its participation since 2012, (b) flowers grew in volume means; thus they were placed on the border between the quadrant of optimal insertion and the one of lost opportunities, (c) cocoa was found to be the best product among them for its position and efficiency. The research stated that Cocoa performing may be related to its exported valued continuous constant growth and participation in the world market.

Sellamén and Camacho (2012), analyzed the international competitiveness of the Colombian blackberry-raspberry in the 2003-2007 period along with its potential international markets. The research employed the theories provided by Balassa (1964 and 1970) and Schwartz, Ibarra, \& Adam, (2007). The research found that that the Colombian blackberry-raspberry had both productive and competitive worldwide potential. In consequence, the Colombian state encourages exports to the markets of Canada, the United States, the United Kingdom and France. Laura and Luis (2019) explored the evolution of the Argentinean exports from 1985 to 2010. The researchers found that natural resources are the main Argentinean export. By employing the Fajnzylber competitiveness matrix, they encountered that the developed countries have determined the Argentinean export structure, however, nowadays, emerging Asian countries have replaced them. Pippinato, Di Vita, and Brun (2019), aimed to study the Relative Commercial Advantage (RCA), Exports Relative Advantage (ERA) and Imports Relative Advantage (IRA) indices in the European Union honey market. They found that the European Union is strongly import-oriented regarding this product. Finally, Schwartz, Maldonado, Luchsinger, Lizana, and Kern (2018), estimated the Chilean and Peruvian Hass avocado competitive business export during the 2009-2014 period by using the market insertion matrix [MIM]. They concluded that both countries were the most competitive in the avocado export business; also, it was found that Peru reached a highly competitive position and had great opportunities for export growth.

\section{Methodology}

This section presents a brief analysis of the competitiveness indicators applied to the study. Descriptive statistics is shown in Appendix A and B.

\subsection{Relative Trade Balance - RTB}

This index explains the relationship that arises from the difference between the flow of total exports and imports, as a numerator, and the trade balance achieved by the evaluated product, as a denominator (Ministerio de Agricultura y Desarrollo Rural: Observatorio Agrocadenas Colombia, 2005a). This index allows to identify better competitive conditions for exported products (Ministerio de Agricultura y Desarrollo Rural: Observatorio Agrocadenas Colombia, 2005b). Moreover, this index provides values interpreted as follows: (a) between zero and one [0 <> 1], it means that the evaluated country is a net exporter of the analyzed product, as well as it must be discarded as a possible market destination; and (b) between minus one and zero, [0 <> - 1], will indicate that the evaluated country is a net importer of the product, at the same time such country should be considered as a potential destination market (Ministerio de Agricultura y Ganadería de Costa Rica, 2019).

$$
\mathrm{RTB}=(\mathrm{Xij}-\mathrm{Mij}) /(\mathrm{Xij}+\mathrm{Mij})
$$

Where:

$\mathrm{Xij}=$ Volume of product " $\mathrm{i}$ ” exported in a " $\mathrm{j}$ ” country, expressed in tons.

Mij= Volume of product " $\mathrm{i}$ " imported in a " $\mathrm{j}$ " country, expressed in tons.

\subsection{Tradability - $T$}

It adds good's origin country data to the trade balance index (Ministerio de Agricultura y Desarrollo Rural: Observatorio Agrocadenas Colombia, 2005a). Then, it allows a clear picture of the place where the product is more competitive by considering both external and domestic consumption (Ministerio de Agricultura y Desarrollo Rural: Observatorio Agrocadenas Colombia, 2005b). According to the Ministry of Agriculture and Livestock of Costa Rica (2019), the values of this index can be interpreted as follows: (a) greater than zero [>0], the country is a competitive exporter due to excess offer [(X-M>0)]; and (b) when it is less than zero [<0the country is non-competitive import substituting country, due to its demand excess $[(\mathrm{X}-\mathrm{M}<0)]$.

$$
\mathrm{Tij}=(\mathrm{Xij}-\mathrm{Mij}) /(\mathrm{Qij}+\mathrm{Mij}-\mathrm{Xij})
$$

Where:

Qij= "i”" volume production in a "j" country, expressed in tons. 
Also, the tradability indicator is build on two sub-indicators: (a) Export Openness Degree [EOD], and (b) Import Penetration Degree [IPD].

\subsubsection{Export Openness Degree - EOD}

It shows the capacity of a particular productive sector to serve the evaluated country domestic as well as the external ones (Ministerio de Agricultura y Desarrollo Rural: Observatorio Agrocadenas Colombia, 2005a). Then, if the obtained ratio approaches to zero value, the country is able to serve only the domestic market, if the result is close to one, the country's export capacity can meet its international duties without unnatending its domestic demand (Ministerio de Agricultura y Desarrollo Rural: Observatorio Agrocadenas Colombia, 2005b). In consequence, competitiveness is improved. This index is expressed as:

$$
\mathrm{EOD}=\mathrm{Xij} /(\mathrm{Qij}+\mathrm{Mij}-\mathrm{Xij})
$$

\subsubsection{Import Penetration Degree - IPD}

It shows the capacity of a country's productive sector to serve its domestic market. Hence, if the domestic demand is not satisfied, imports will be necessary. Then, the domestic productive sector competitiveness will fall (Ministerio de Agricultura y Desarrollo Rural: Observatorio Agrocadenas Colombia, 2005a). It also can be understood as the competiveness reduction by a greater demand of imported products when being compared with self-sufficient countries (Ministerio de Agricultura y Desarrollo Rural: Observatorio Agrocadenas Colombia, 2005b). IPD is estimated as follows:

\subsection{Net Revealed Comparative Advantage - NRCA}

$$
\mathrm{IPD}=\mathrm{Mij} /(\mathrm{Qij}+\mathrm{Mij}-\mathrm{Xij})
$$

Developed by Balassa in 1965, it attempts to get the comparative advantage. Balassa states that the comparative advantage can be estimated by the trade exchange flow (Macías, 2011). This index [NRCA] is the difference of the Revealed Exports Comparative Advantage [RECA] index and the Revealed Imports Comparative Advantage [RICA] index. Furthermore, each of these components come from other previous calculations as seen in equation 6 and 7.For one hand, if NRCA is greater than one, the exportable supply of a country exceeds its import demand, then a the country has a comparative advantage. On the other hand, if NRCA value is negative, the evaluated country has a revealed comparative disadvantage because of its more imports exceeding demand than its exportable supply (Macías, 2011).

$$
\begin{gathered}
\text { NRCAij }=\text { RECAij }- \text { RICAij } \\
\text { RECAij }=\left[\left(\text { Xij } /\left(\sum \text { Xij }- \text { Xij }\right)\right] /\left[\left(\text { Xim } /\left(\sum \text { Xim }- \text { Xim }\right)\right]\right.\right. \\
\text { RICAij }=\left[\left(\text { Mij } /\left(\sum \text { Mij }- \text { Mij }\right)\right] /\left[\left(\text { Mim } /\left(\sum \text { Mim }- \text { Mim }\right)\right]\right.\right.
\end{gathered}
$$

Where:

$\mathrm{X}=$ Exports value

$\mathrm{M}=$ Imports value

$\mathrm{j}=$ Country analyzed

$\mathrm{i}=$ Product studied

$\mathrm{m}=$ World

Macias (2011) states: “(a) positive NRCA means that the country is a net exporter of the product; (b) when the value fluctuates between zero and one, it means that it has no comparative advantage, and (c) if the value is between one and infinity, there is a comparative advantage "( p. 520-521). Hence, it is possible that a country could be a net exporter even when it does not have a revealed comparative advantage. In consequence, Laursen in Macías (2011) incorporates the concept of Symmetric Revealed Comparative Advantage as portrayed in equation 8, which asks for a number greater than one for the evaluated country to be considered as a net exporter and owner of comparative advantage.

$$
\text { SRCAij }=(\text { NRCAij }-1) /(\text { NRCAij }+1)
$$

\subsection{Market Insertion Matrix - MIM}

The Observatorio de Agrocadenas (2005) states that this index is made of positioning and efficiency. Also, the aforementioned index provides a product competitiveness and its adaptability (Ministerio de Agricultura y Desarrollo Rural: Observatorio Agrocadenas Colombia, 2005). 
According to Fajnzylber (1988) competitiveness can be evaluated with eight factors; however, he synthesizes it in two basic elements (Fajnzylber 1991) by "combining the concepts of positioning and efficiency, then it is possible to distinguish four strategically different situations" (p. 151).

1. Positive insertion: positioning and efficiency are positive.

2. Insertion with missed opportunities: positive positioning and negative efficiency.

3. Insertion with vulnerability: negative positioning and positive efficiency.

4. Insertion in withdrawal: positioning and efficiency are negative.

These two components are calculated as follows:

\subsubsection{Positioning}

"It is measured through the Annual Growth Rate of a country's exports to the international market" (Schwartz et al. 2007, p. 182).

$$
\mathrm{P}=\mathrm{TCAij}=\left[(\mathrm{Xb} / \mathrm{Xa})^{\wedge}(1 /(\mathrm{b}-\mathrm{a})]-1\right.
$$

Where "i" belongs to the product studied, "a" and " $\mathrm{b}$ " the initial and final years studied, correspondingly.

\subsubsection{Efficiency}

"It is the Annual Growth Rate of a product exports share in the total worldwide exports" (Schwartz et al. 2007, p. 182).

$$
\mathrm{E}=\mathrm{TCA} \text { part.Xij= }[(\text { part.Xjb }) /(\text { part.Xja }) \wedge(1 /(\mathrm{b}-\mathrm{a}))]-1
$$

Where:

$$
\text { part.Xij= Xij / } \sum X i
$$

\section{Results}

Table A1 shows that from 2010 to 2017, the principal American grape import partner by volume and value was Chile. The table also shows that Mexico was the American grapes main destiny in volume, while the American grapes principal buyer in value was Canada.

Table A2 shows that in the period 2010-2017, the Dutch grape principal supplier was South Africa both in volume and value terms. Also, the table shows that Dutch grapes principal buyers are Germany both in volume and value.

Both Table A1 and A2 exhibits that Italy produced the highest grapes volume worldwide in the period 2010-2017.

Table 1. Grape suppliers' competitiveness in United States market (2010-2017 average)

\begin{tabular}{lrrrrrrrrr}
\hline Countries & RTB & T & EOD & IPD & Pos\% & Ef\% & SRCA & Part-X \% & Part-M \% \\
\hline Chile & 0.999 & 0.1678 & 0.1679 & 0.0001 & -4.0 & -3.7 & -0.362 & 38 & 0.10 \\
Mexico & 0.590 & 0.5312 & 0.7104 & 0.1791 & 6.5 & 4.1 & 0.329 & 4 & 13.62 \\
Peru & 1.000 & 0.1140 & 0.1140 & 0.0000 & 25.6 & 16.7 & 0.029 & 13 & 0.31 \\
Brazil & 0.865 & 0.0037 & 0.0037 & 0.0000 & -21.8 & -7.2 & -0.552 & 3 & 5.59 \\
South Africa & 0.981 & 0.0001 & 0.0001 & 0.0000 & 13.8 & 1.2 & -0.994 & 12 & 1.06 \\
Canada & 0.901 & 0.0186 & 0.0196 & 0.0009 & -11.5 & -0.1 & -0.760 & 0 & 47.72 \\
Italy & 0.998 & 0.0001 & 0.0001 & 0.0000 & -6.1 & -0.4 & -0.984 & 21 & 6.00 \\
Spain & -0.220 & -0.0000 & 0.0000 & 0.0000 & 78.2 & 0.6 & -1.005 & 8 & 8.71 \\
South Korea & 0.927 & 0.0006 & 0.0007 & 0.0000 & -3.6 & 21.1 & -0.284 & 0 & 16.67 \\
Argentina & 0.835 & 0.0000 & 0.0000 & 0.0000 & -55.2 & -31.9 & -0.997 & 1 & 0.21 \\
\hline
\end{tabular}

According to Table 1, the Relative Trade Balance Index [RTB] had a variation between 1.00 and -0.220 . The three countries with the highest score are considered competitive. Those countries were (a) Peru, which obtained the highest result, (b) Chile and (c) South Africa. All of them were considered as grape net exporters. In consequence, both Chile and South Africa cannot be considered as potential destinies of the Peruvian grape. Spain was the only country that got a negative index. Hence, Spain is not a competitive country, but it is a potential Peruvian grape destiny (Ministry of Agriculture and Livestock of Costa Rica, 2019). 
The Tradability Index [T] ranged between -0.000 and 0.531 . Hence it can be stated that (a) Mexico; (b) Chile; and (c) Peru, are the three most competitive grape exporters. According to the EOD component, the competitiveness of Spain and Argentina are decreasing since their capacity cannot satisfy their domestic. Moreover, according to the IPD component, Italy was considered competitive since almost all its grape production was destined to exports (Ministry of Agriculture and Livestock of Costa Rica, 2019).

The SRCA index exhibits that Chile, Mexico, Peru, South Africa, Canada, Italy, and Argentina, were net exporting countries of fresh grapes. Among them, Mexico and Peru were the only countries that reached a comparative advantage of the product since they got a result greater than 0 .

Finally, Table 1 shows that Chile was the country with the highest volume of exports since its $37.6 \%$ of participation.

Table 2. Grape competitiveness indicators for main exporters to the Netherlands (average 2010-2017)

\begin{tabular}{lrrrrrrrrr}
\hline Countries & RTB & T & EOD & IPD & Pos\% & Ef\% & SRCA & Part-X \% & Part-M \% \\
\hline South Africa & 0.999 & 0.0709 & 0.0710 & 0.0001 & 1.7 & 1.1 & 0.494 & 12.9 & 4.9 \\
Peru & 0.927 & 0.0000 & 0.0001 & 0.0002 & 17.2 & 16.6 & -8.436 & 13.6 & 1.5 \\
India & 0.621 & 0.0000 & 0.0000 & 0.0001 & 12.8 & 12.1 & 0.999 & 0.0 & 0.0 \\
Chile & 0.968 & 0.0000 & 0.0000 & 0.0000 & -8.0 & -3.8 & 2.119 & 39.9 & 0.4 \\
Brazil & 0.907 & 0.0000 & 0.0000 & 0.0001 & -2.2 & -7.3 & 0.510 & 2.9 & 25.7 \\
Egypt & 0.831 & 0.0000 & 0.0000 & 0.0005 & 2.5 & -0.5 & 0.998 & 0.0 & 0.0 \\
Namibia & 0.819 & 0.0004 & 0.0005 & 0.0004 & -7.3 & -1.1 & 1.001 & 0.0 & 0.0 \\
Spain & 0.463 & 0.0000 & 0.0000 & 0.0000 & 8.8 & 0.5 & -1.050 & 8.7 & 39.7 \\
Germany & -0.037 & -0.0000 & 0.0000 & 0.0009 & -8.2 & -3.0 & 0.978 & 0.0 & 0.4 \\
Italy & 0.504 & 0.00000 & 0.0000 & 0.0000 & 0.5 & -0.5 & 24.216 & 22.0 & 27.4 \\
\hline
\end{tabular}

According to Table 2, the Relative Trade Balance [RTB] index, had a variation between 1,000 and $-0,038$. The three countries with the highest score were South Africa, Chile, and Peru. Hence, these countries were considered competitive and grape net exporters. As in Table 1, both South Africa and Chile cannot be taken as possible destination markets for the fresh Peruvian grapes. Germany was not considered competitive since its negative outcome. However, it can be a potential destination market for fresh Peruvian grapes (Ministry of Agriculture and Livestock of Costa Rica, 2019).

The Tradability Index [T] ranged between 0.000 and 0.531 . Hence, Mexico, Chile, and Peru were considered the three most competitive fresh grapes exports countries. According to the EOD component, Spain's competitiveness decreased since its incapability of satisfying its domestic demand. The IPD sub-index states that Chile was considered competitive since it allocates a large part of its grape national production for export; then its IPD outcome is closer to zero than any other analyzed country (Ministry of Agriculture and Livestock of Costa Rica, 2019).

The SRCA index indicates that Namibia, India, Egypt, Germany, Brazil, and South Africa, were fresh grapes net exporting countries. Among them Chile and Italy were the countries that reached a comparative advantage of the product since their highest results in such index.

Finally, Chile was the country with the highest volume of exports since its $39.9 \%$ of participation, followed by Italy, with $22 \%$, and Peru with $13.6 \%$. 


\section{Discussion}

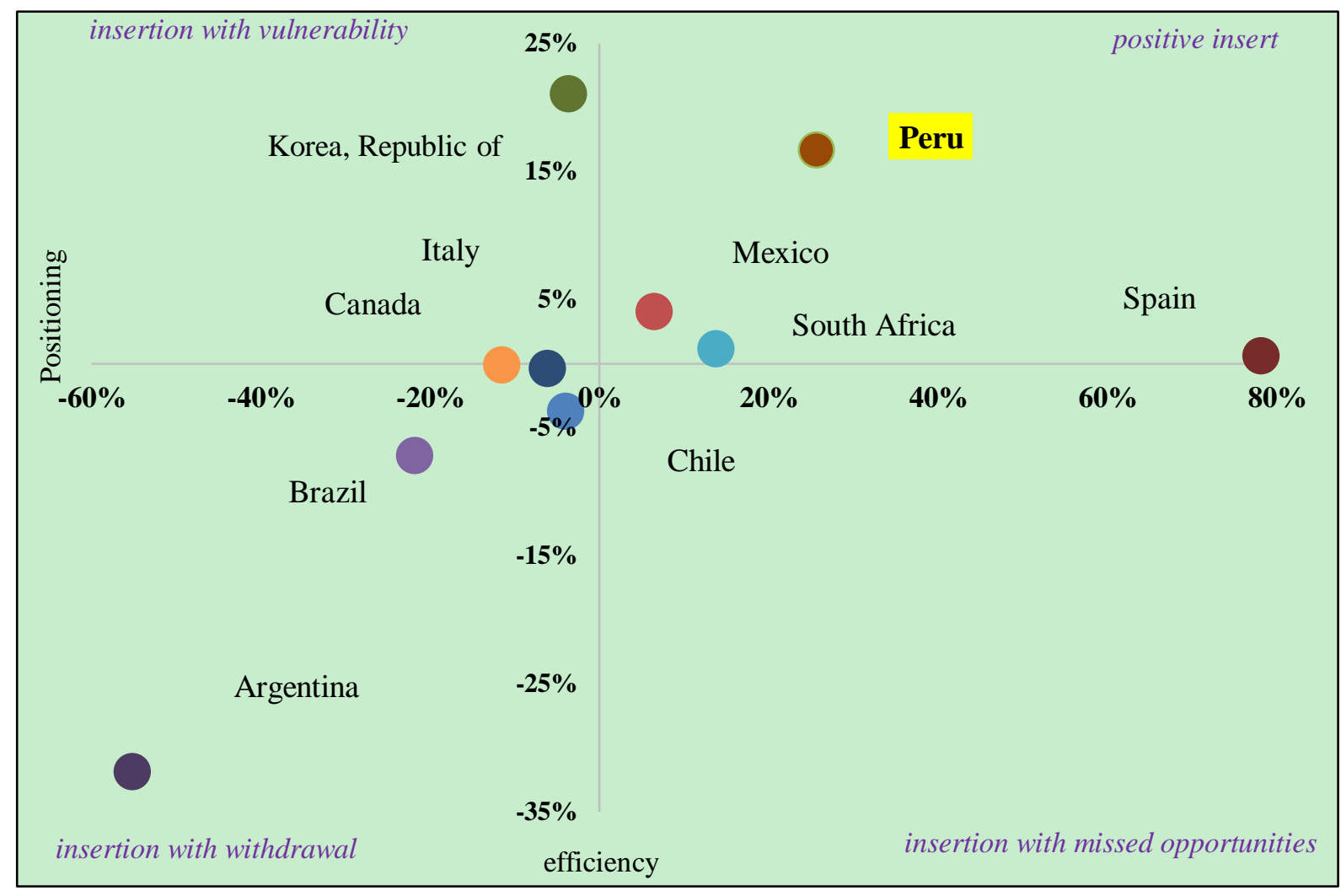

Figure 1. Insertion matrix of the US grape market (2010-2017)

Figure 2 shows ten countries which belong to the four insertion types in the US market in the 2010-2017 period. The first quadrant, which is called Positive Insertion, is composed of Peru, Mexico, South Africa, and Spain. Peru is the most competitive country since it obtained the best results in both positioning [25.64\%] and efficiency [16.70\%]. Although Spain had the best positioning index, its efficiency level was little [0.61\%]. Mexico had both positive positioning and efficiency indices, but they were low. South Africa presented a positioning index of $13.76 \%$ but it is less efficient than Mexico. The participation American markets for the four countries were higher in 2017 than 2010.

The current study found that although Chile was the main American market supplier, this country was not found to be competitive. Valencia and Duana (2019) as well as Kim (2019), also a similar phenomenon.

Spain is a rookie supplier in the American market; then, this country had lower grapes volume than Peru, Mexico, and South Africa. In consequence, Spain had efficiency favorable levels as well as positioning challenges. Peru, is the third highest volume supplier to the American market. This country increased both exports levels and T, EOD, and SRCA indexes as Pippinato et al. (2019), also encountered. In consequence, Peru was able to increase its efficiency and positioning. A study carried by Schwartz (2018) found similar results for another agricultural product, too.

The second quadrant, which was called Insertion with Missed Opportunities, did not have any country in since none of the studied countries had a positive positioning index and a negative efficiency index. In the third quadrant, which was called Insertion with Vulnerability, South Korea was the only country in. This country had a negative positioning index [-3.63\%], which meant that their exported value in 2017 to the United States market was much lower compared to 2010. Nonetheless, it was the most efficient country [21.05\%] which meant that its world exports of fresh grapes in 2017 was more representative than in 2010.

For South Korea it is important to start increasing its exports volume to the American market in the following years as suggested by Sellamén y Camacho (2012). Furthermore, South Korea can also find another markets with more 
favorable conditions as empirically suggested by Fabrini Diniz (2017) in their study about the Brazilian oranges.

The fourth quadrant, which was called Insertion with Withdrawal, represent the countries that are not considered competitive (Schwartz et al., 2007). These countries were Argentina, which was the least efficient [-55.17\%] and the worst positioned [-31.88\%] followed by Brazil, Chile, Italy, and Canada. Countries in this quadrant had a lower participation both in the world exports and in the American market in the period analyzed.

A possible explanation for the Argentinean unfavorable position is the change in its exports structure. Before, Argentina along with other Latin American countries were the American primary resources main suppliers; however, Asia replaced them in the recent years as suggested by Laura y Luis (2019).

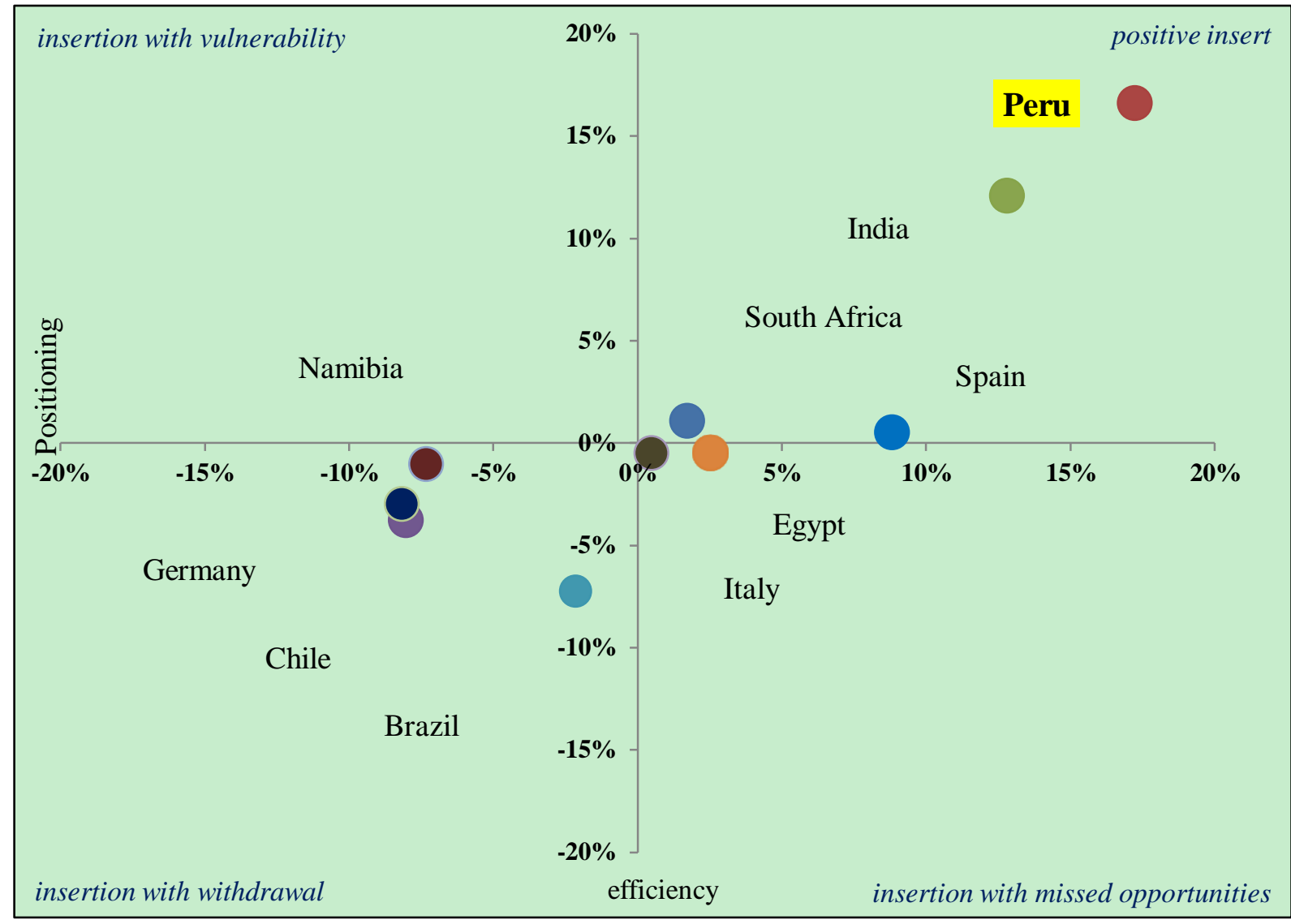

Figure 2. Insertion matrix of the Dutch grape market (2010-2017)

Figure 3 portrays the market insertion classification of the analyzed countries in the Dutch grape market. In the first quadrant, which was composed of competitive countries, Peru was the most competitive country due to its highest positioning index [17.23\%]; moreover, Peru was considered the most efficient supplier [16.60\%]. In this quadrant Peru was followed by India, Spain and South Africa. All countries located in this quadrant increased their fresh grapes exported both in volume value to the Dutch market.

Jambor et al., (2017) recommend to evaluate the market through the SRCA index. Hence, it according to this index the peruvian grape should increase its performance regarding the Dutch market because both South Africa and Indica became the two main suppliers of the Dutch market.

For Gómez (2017) quality is a determinant that influences the product demand but it can be overwhelmed due to the imitability reached by a competitor. Such fact and SRCA number [-8.436], may predict the comparative advantage losing of the peruvian grape in the Dutch market in the following years.

In the second quadrant, Egypt had a positioning index of $2.51 \%$ and a negative efficiency index of $-0.49 \%$; in the case of Italy, it registered the lowest positioning index [0.47\%] and a negative efficiency outcome [-0.47\%]. Both countries grapes exported values were decreasing. 
The quadrant called Insertion with withdrawal was empty since no country had a negative positioning outcome and positive efficiency value.

In the last quadrant, Insertion with missed opportunities, are located countries that had negatives values in both positioning and efficiency indices; therefore, these countries are labelled as non-competitive. Figure 2 exhibits that in this quadrant Germany, presented the lowest negative positioning index $[-8.17 \%]$ as well as a negative efficiency index [-2.98\%]. Moreover, in this quadrant is located Chile [-8.04\%; -3.80\%]; Brazil [-2.15\%; -7.26\%], and Namibia $[-7.3 \% ; 1.1 \%$.]. Countries decreased their fresh grapes exported both value and quantity to Netherlands. Then, their participation reduced in the period analyzed. The results seem to match with the findings of Camino et al., (2016) who encountered that the Equatorial bananas have lost its efficiency due to the reduction of its exports volume and the new competitors showing up in the international market.

In summary, Peru, South Africa, and Mexico were found to be competitive in the American market; while Peru, South Africa, India, and Spain were labelled as competitive ones in the Dutch market. Therefore, only Peru and South Africa were competitive in both markets. Hence, both countries are net exporters that could attend their domestic demand as well as the international market. It is not surprising, then, that for these countries their exported value and participation grew in the analyzed period. Consequently, in a Peruvian perspective South Africa is a strong competitor in the American and Dutch markets. Also, it can be stated that both Germany and Spain markets can be considered as potential destination markets for fresh Peruvian grapes.

For this study, real data on the production, import, and export of fresh Peruvian grapes was considered, as well as data that took into account other major grape exporters worldwide. Still, future research could assess other variables, such as production productivity and investment in the agro-exporting sector of grapes, in order to best estimate the relationship and contribution of these to the product's competitiveness in a global marketplace.

\section{Conclusions}

The Peruvian fresh grape competitive dynamics has experienced a positive growth in its exports to the world. American and Dutch markets were not the exception in the 2010-2017 period. Focusing in these highly important markets, South Africa is the main Peruvian competitor. Moreover, Chile is a competitor with big participation volume, but the Chilean grape has lost positioning levels; thus, its competitiveness has fallen.

Unless conditions are changed, Dutch market will cease to be one of the main markets for the Peruvian grape. Factors such as the exported quantities decreasing, rise of countries with a better SRCA, and the showing up of net export countries with the capability to position in the Dutch market are reasons to forecast the Peruvian grape fall in the Dutch market, even though analyzed indexes' results were found to be positive in the period studied.

Since it is necessary to increase the efficiency and positioning, the following actions should may be taken by the Peruvian grape exporters: (a) consolidate the Peruvian grape competitiveness in both the American and Dutch markets, (b) prioritize the competitive advantage earned in the American market; then, give less importance to the Dutch market, (c) give more importance to the German and Spanish markets. Whatever the chosen alternative would be, every grape producer should continue to increase its production per hectare and its product quality

Product developing actions carried by the grape agro-export sector displaced some countries from their competitive hegemony. Then, it is important to maintain and consolidate the Peruvian grape competitiveness in the analyzed two destination markets. For such purposes it is necessary to manage properly contributing components that boost both efficiency and positioning. Also, it is important to increase the production per hectare planted volume as well as the quality of the grape taking into consideration the markets' needs.

According to Relative Trade Balance index, Germany and Spain are countries with conditions of new potential markets for the analyzed product. Then, the Peruvian grape producers could also attend these markets based on their previous experience in markets where they became competitive.

\section{References}

Balassa, B. (1965). Trade liberalization and revealed comparative advantage. In the Manchester School of Economic and Social Studies (pp. 99-123).

Cámara de Comercio de Lima [CCL]. (2019, October 23). CCL: Exportaciones de uvas frescas crecieron 18\% a agosto de este año. Recuperado el 5 de enero de 2020. Retrieved from https://gestion.pe/economia/ccl-exportaciones-de-uvas-frescas-crecieron-18-a-agosto-de-este-ano-noticia/?ref=gesr

Camino Mogro, S., Andrade Díaz, V., \& Pésantez Villacís, D. (2016, May-August). Posicionamiento y eficiencia del banano, cacao y flores del Ecuador en el mercado mundial. Revista Ciencia UNEMI, 9(19), 48-53. 
Fabrini Diniz, A. (2017, June). Vantagem Comparativa Revelada da Agroindustria Nacional no Período 2003 -2014. Revista Paranaense de Desenvolvimiento, 38(132), 91-105.

Fajnzylber, F. (1991, August). Inserción internacional e innovación institucional. Revista de la CEPAL, (44), 149-178. https://doi.org/10.18356/c3a8fcf5-es

Fajnzylber, F. (1988, December). Competitividad internacional: Evolución y lecciones. Revista de la CEPAL, (36), 7-24. https://doi.org/10.18356/c3a8fcf5-es

FAOSTAT a. (2019, November 14). Datos: Cultivos. Recuperado el 14 de noviembre de 2019. Retrieved from http://www.fao.org/faostat/es/\#data/QC

FAOSTAT b. (2019, November 14). Exportaciones: Países por producto. Recuperado el 14 de noviembre de 2019, de Ranking de los 20 principales países exportadores. Retrieved from http://www.fao.org/faostat/es/\#rankings/countries_by_commodity_exports

FAOSTAT c. (2019, November 15). Importaciones: Países por producto. Recuperado el 15 de noviembre de 2019, de Ranking de los 10 principales países importadores. Retrieved from http://www.fao.org/faostat/es/\#rankings/countries_by_commodity_imports

Gómez, C. (2017, July 27). Estructura de las exportaciones y competitividad: El caso de los países de la Asociación de Naciones de Sudeste Asiático. Análisis Económico, XXXII(81), 75-92.

ITC - TRADE MAP. (2019, November 14). Lista de los mercados importadores para un producto exportado por Perú.

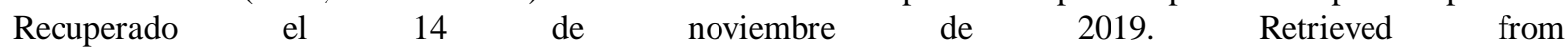
https://www.trademap.org/Country_SelProductCountry.aspx?nvpm=3\%7c604\%7c\%7c\%7c\%7c080610\%7c\%7c $\% 7 \mathrm{c} 6 \% 7 \mathrm{c} 1 \% 7 \mathrm{c} 1 \% 7 \mathrm{c} 2 \% 7 \mathrm{c} 1 \% 7 \mathrm{c} 1 \% 7 \mathrm{c} 2 \% 7 \mathrm{c} 1 \% 7 \mathrm{c}$

Jambor, A., Timea, A., \& y Koroshegyi, D. (2017). The Export Competitiveness of Global Cocoa Trades. AGRIS on-line Papers in Economics and Informatics, IX(3), 27-37.

Kim, M. (2019, May 17). Export Competitiveness of India's textiles and clothing sector in the United States. Economies, 1-17.

Laura Fernández, V., \& Luis Curado, M. (2019, April). La matriz de competitividad argentina: Evolución de la inserción internacional del país ante la controversia de los recursos naturales, Revista de la CEPAL, (127), 75-100. https://doi.org/10.18356/11ea3ef5-es

Laursen, K. (1998, December 3). Revealed Comparative Advantage and the Alternatives as Measures of International Specialisation. Danish Research Unit for Industrial Dynamics.

Macías Macías, A. (2011, July-September). México en el mercado internacional del aguacate. Revista de Ciencias Sociales, XVII(3), 517-532.

Ministerio de Agricultura y Desarrollo Rural: Observatorio Agrocadenas Colombia. (2005, March). La Cadena del Tabaco en Colombia: Una mirada global de su estructura y dinámica (1991 - 2005). Recuperado el 2019 de noviembre de $17 . \quad$ Retrieved from http://bibliotecadigital.agronet.gov.co/bitstream/11348/6341/1/2005112164853_caracterizacion_tabaco.pdf

Ministerio de Agricultura y Desarrollo Rural. Metodología de Cálculo de Indicadores de Competitividad. Bogotá: Observatorio de Agrocadenas Colombia. (noviembre de 2005). La Cadena de Azúcar en Colombia. Recuperado $\begin{array}{llllll}\text { el } & 12 & \text { de } & \text { diciembre } & \text { de } & \text { Retrieved }\end{array}$ https://repository.agrosavia.co/bitstream/handle/20.500.12324/18805/43861_55620.pdf?sequence=1\&isAllowed=y

Ministerio de Agricultura y Ganadería de Costa Rica. (2019, December 16). Infoagro Costa Rica. Recuperado el 16 $\begin{array}{lllll}\text { de } & \text { diciembre } & \text { de } & \text { Retrieved }\end{array}$ http://www.infoagro.go.cr/EstadisticasAgropecuarias/AGROCOMERCIALES/Documents/Balanza-comercial-r elativa.pdf

Ministerio de Comercio Exterior y Turismo- [MINCETUR]. (2019, June 12). Perú es el tercer exportador mundial de uva ¿qué empresas hacen los mayores envíos? Recuperado el 6 de enero de 2010. Retrieved from https:/gestion.pe/economia/peru-tercer-exportador-mundial-uva-empresas-registraron-mayores-envios-269888noticia/?ref=gesr

Moreyra, J. C. (2019, March). La uva peruana: Una oportunidad en el mercado mundial. Recuperado el 9 de enero de 2020.

Retrieved

from 
http://agroaldia.minagri.gob.pe/biblioteca/download/pdf/tematicas/f-taxonomia_plantas/f01-cultivo/2019/Infor me-uva-peruana.pdf

Pat, V., Caamal, I., Caaml, Z., \& y Jerónimo, F. (2016, July-December). Análisis de los indicadores de competitividad del cultivo de la fresa de México en el mercado mundial. Economía, (68), 45-63.

Pippinato, L., Di Vita, G., \& y Brun, F. (2019). Trade and Comparative Advantage Analysis of the UE honey sector with a focus on the Italian market. Quality - Acces to Succes, (20), 485-492.

Schwartz, M., Ibarra, K., \& y Adam, C. (2007). Actas VI Congreso Mundial del Aguacate. Indicadores de competitividad de la industria exportadora chilena de palta (Aguacate), (pág. 3). Viña del Mar.

Schwartz, M., Maldonado, Y., Luchsinger, L., Lizana, L., \& Kern, W. (2018). Competitive Peruvian and Chilean avocado export profile. Ethical and Technological Issues, 1079-1084. https://doi.org/10.17660/ActaHortic.2018.1194.154

Sellamén Garzón, A., \& Camacho Murillo, A. (2012, January-June). The international competitiveness and target markets of Colombian blackberries. Criterio Libre, $10(16), \quad 23-42$. https://doi.org/10.18041/1900-0642/criteriolibre.2012v10n16.1154

Sociedad de Comercio Exterior del Perú - [COMEX]. (2019, November 10). Paltas, uvas y arándanos peruanos lideran ranking de productos más demandados por el mundo. Recuperado el 6 de enero de 2020. Retrieved from https://gestion.pe/economia/paltas-uvas-y-arandanos-peruanos-lideran-ranking-de-productos-mas-demandadospor-el-mundo-noticia/?ref=gesr

Stellian, R., \& y Danna-Buitrago, J. (2017, August). Competitividad de los productos agropecuarios colombianos en el marco del tratado de libre comercio con los Estados Unidos: análisis de las ventajas comparativas. CEPAL, (122), 139-162. https://doi.org/10.18356/7fc7c097-es

Superintendencia Nacional de Administración Tributaria - [SUNAT]. (2019, November 15). Estadísticas y Estudios. Recuperado el 15 de noviembre de 2019, de Nota Tributaria y Aduanera. Retrieved from http://www.sunat.gob.pe/estadisticasestudios/exportaciones.html

Valencia, K., \& y Duana, D. (2019, June 2). La competitividad del comercio de la uva en el mercado internacional y en Estados Unidos: el caso de México y Perú. CIMEXUS, XIV(1), 59-77. https://doi.org/10.33110/cimexus 14010

\section{Appendix A}

\section{United States Grapes Trade Balance in the Period 2010-2017}

Table A1. Descriptive statistics

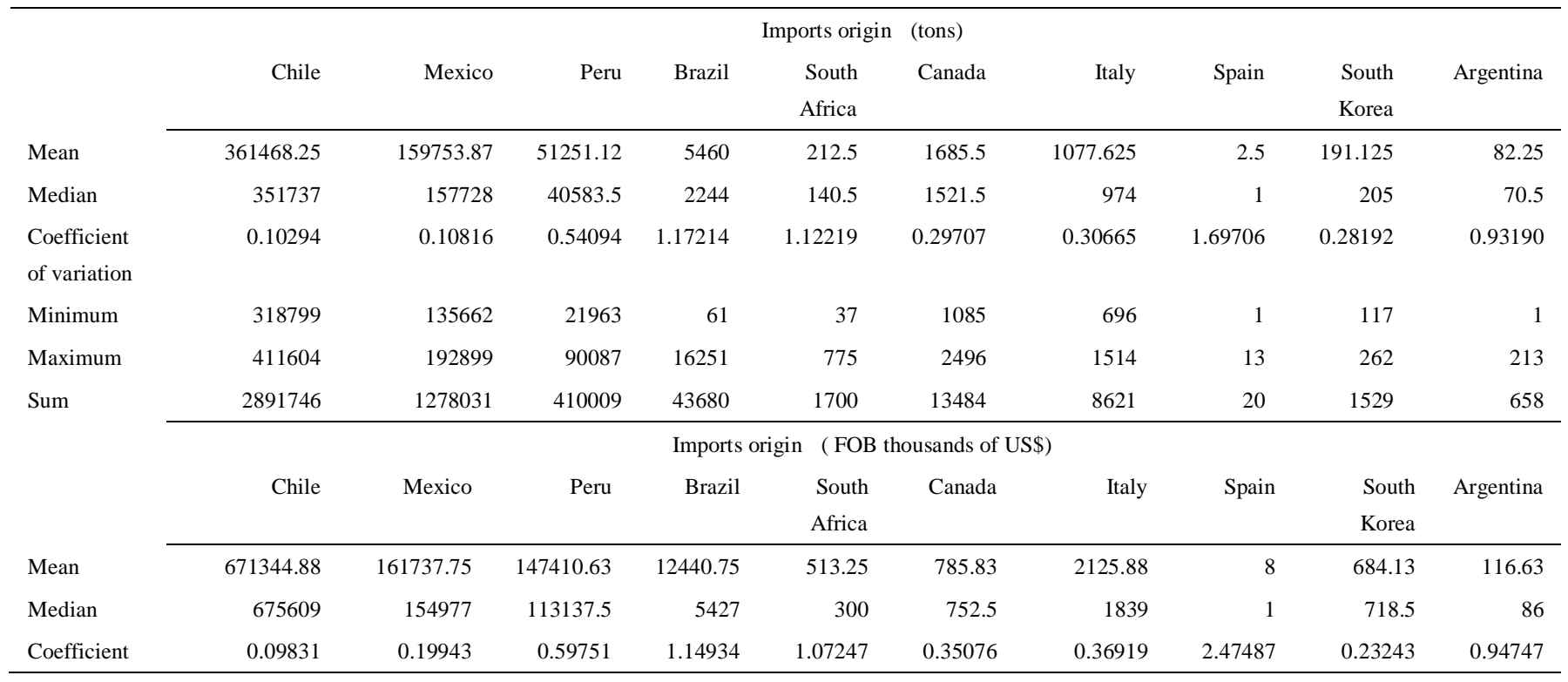




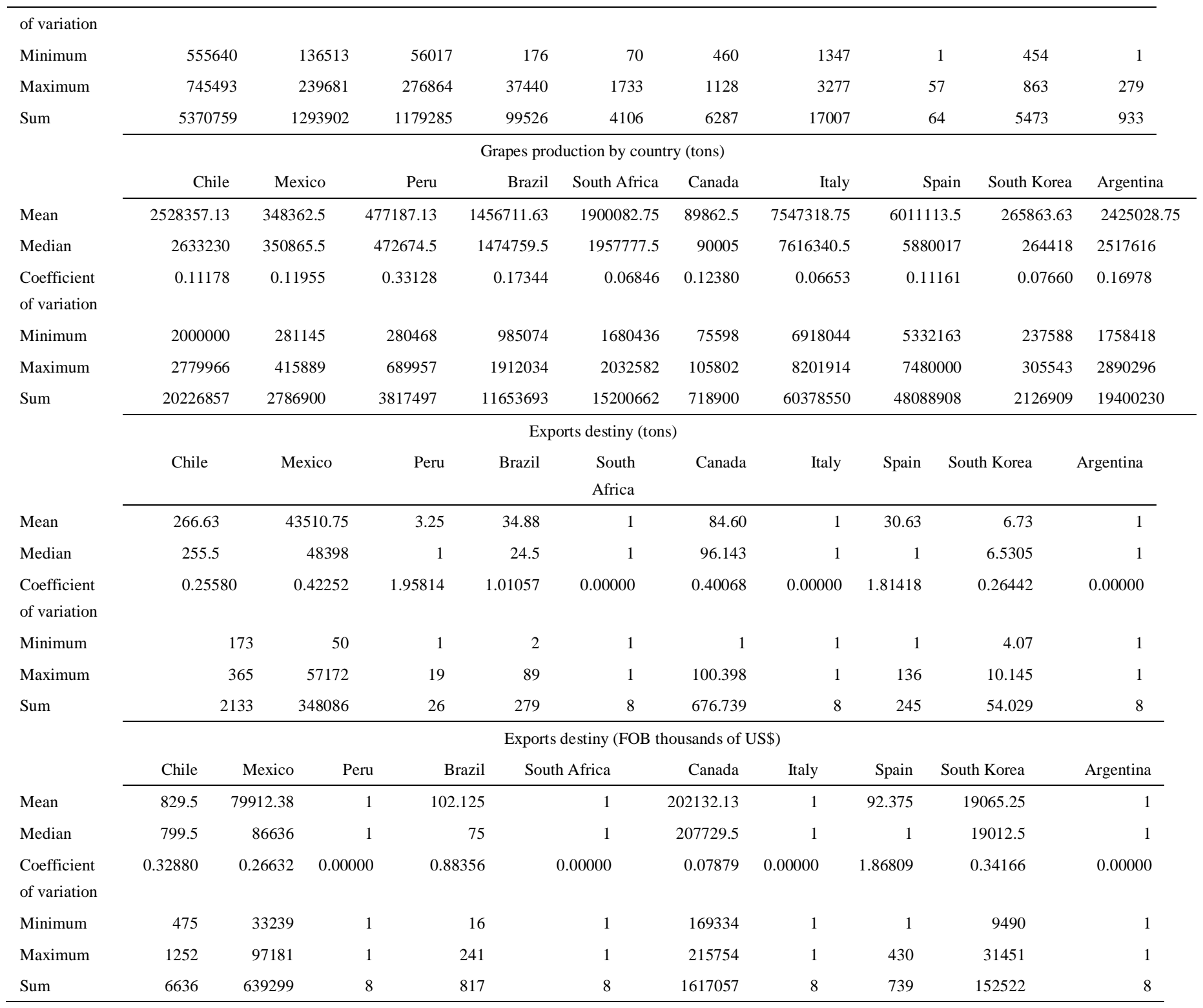




\section{Appendix B}

\section{Dutch Trade Balance in the Period 2010-2017}

Table B1. Descriptive statistics

\begin{tabular}{|c|c|c|c|c|c|c|c|c|c|c|}
\hline & \multicolumn{10}{|c|}{ Imports origin (tons) } \\
\hline & South Africa & Peru & India & Chile & Brazil & Egypt & Namibia & Spain & Germany & Italy \\
\hline Mean & 125839.4 & 32128 & 32612 & 65648.75 & 19515.25 & 27487.5 & 9785.25 & 6169.25 & 2307.88 & 13933.63 \\
\hline Median & 124532 & 36307 & 33257 & 66751.5 & 22575 & 23073.5 & 10083.5 & 6659 & 2267 & 13979.5 \\
\hline $\begin{array}{l}\text { Coefficient of } \\
\text { variation }\end{array}$ & \multicolumn{9}{|c|}{ variation } & 0.08228 \\
\hline Minimum & 115115 & 11024 & 2505 & 43865 & 1786 & 226 & 745 & 865 & 1168 & 12041 \\
\hline Maximum & 137403 & 46255 & 57166 & 85155 & 26639 & 100548 & 14722 & 8072 & 3279 & 15399 \\
\hline \multirow[t]{3}{*}{ Sum } & 1006715 & 257024 & 260896 & 525190 & 156122 & 219900 & 78282 & 49354 & 18463 & 111469 \\
\hline & \multicolumn{10}{|c|}{ Imports origin (FOB thousands of US\$) } \\
\hline & South Africa & Peru & India & Chile & Brazil & Egypt & Namibia & Spain & Germany & Italy \\
\hline Mean & 191014 & 65193.13 & 59876.88 & 100845 & 46932.63 & 46180 & 14652.63 & 14895.13 & 5014.37 & 24535.13 \\
\hline Median & 189738.5 & 71995.5 & 54221.5 & 105813.5 & 49618 & 45724.5 & 15032.5 & 15304 & 5150 & 25010 \\
\hline $\begin{array}{l}\text { Coefficient of } \\
\text { variation }\end{array}$ & 0.08194 & 0.34393 & 0.46280 & 0.27933 & 0.25766 & 0.18574 & 0.34632 & 0.21771 & 0.36628 & 0.07393 \\
\hline Minimum & 163225 & 24788 & 22173 & 58303 & 32375 & 33724 & 7894 & 9803 & 2332 & 22207 \\
\hline Maximum & 214411 & 90947 & 94998 & 142436 & 61695 & 58271 & 21668 & 18921 & 7889 & 26481 \\
\hline \multirow[t]{3}{*}{ Sum } & 1528112 & 521545 & 479015 & 806760 & 375461 & 369440 & 117221 & 119161 & 40115 & 196281 \\
\hline & \multicolumn{10}{|c|}{ Grapes production by country (tons) } \\
\hline & South Africa & Peru & India & Chile & Brazil & Egypt & Namibia & Spain & Germany & Italy \\
\hline Mean & 1900082.75 & 477187.13 & 2189880 & 2528357.13 & 1456711.63 & 1521499.5 & 23949.25 & 6011113.5 & 1156666.88 & 7547318.75 \\
\hline Median & 1957777.5 & 472674.5 & 2534170 & 2633230 & 1474759.5 & 1515417.5 & 23441.5 & 5880017 & 1212300 & 7616340.5 \\
\hline $\begin{array}{l}\text { Coefficient of } \\
\text { variation }\end{array}$ & 0.06846 & 0.33128 & 0.33356 & 0.11178 & 0.17344 & 0.10798 & 0.08112 & 0.11161 & 0.09817 & 0.06653 \\
\hline Minimum & 1680436 & 280468 & 880700 & 2000000 & 985074 & 1320801 & 21703 & 5332163 & 952500 & 6918044 \\
\hline Maximum & 2032582 & 689957 & 2922000 & 2779966 & 1912034 & 1703394 & 27203 & 7480000 & 1250000 & 8201914 \\
\hline \multirow[t]{3}{*}{ Sum } & 15200662 & 3817497 & 17519040 & 20226857 & 11653693 & 12171996 & 191594 & 48088908 & 9253335 & 60378550 \\
\hline & \multicolumn{10}{|c|}{ Exports destiny (tons) } \\
\hline & South Africa & Peru & India & Chile & Brazil & Egypt & Namibia & Spain & Germany & Italy \\
\hline Mean & 1 & 1 & 10.63 & 1 & 1 & 8.38 & 1 & 2658.88 & 4474.25 & 4080.38 \\
\hline Median & 1 & 1 & 1 & 1 & 1 & 1 & 1 & 2462 & 3506 & 4145 \\
\hline
\end{tabular}




\begin{tabular}{|c|c|c|c|c|c|c|c|c|c|c|}
\hline Coefficient of & 0.00000 & 0.00000 & 1.75858 & 0.00000 & 0.00000 & 2.49070 & 0.00000 & 0.29884 & 1.06879 & 0.46827 \\
\hline \multicolumn{11}{|l|}{ variation } \\
\hline Minimum & 1 & 1 & 1 & 1 & 1 & 1 & 1 & 1524 & 0 & 496 \\
\hline Maximum & 1 & 1 & 50 & 1 & 1 & 60 & 1 & 3911 & 11285 & 6152 \\
\hline \multirow[t]{3}{*}{ Sum } & 8 & 8 & 85 & 8 & 8 & 67 & 8 & 21271 & 35794 & 32643 \\
\hline & \multicolumn{10}{|c|}{ Exports destiny (FOB thousands of US\$) } \\
\hline & South Africa & Peru & India & Chile & Brazil & Egypt & Namibia & Spain & Germany & Italy \\
\hline Mean & 1 & 1 & 24.25 & 1 & 1 & 6.25 & 1 & 5994.25 & 12892 & 11405.875 \\
\hline Median & 1 & 1 & 1 & 1 & 1 & 1 & 1 & 5673.5 & 11063 & 12438.5 \\
\hline Coefficient of & 0.00000 & 0.00000 & 1.83477 & 0.00000 & 0.00000 & 2.37588 & 0.00000 & 0.33680 & 1.04614 & 0.27159 \\
\hline \multicolumn{11}{|l|}{ variation } \\
\hline Minimum & 1 & 1 & 1 & 1 & 1 & 1 & 1 & 3589 & 0 & 6026 \\
\hline Maximum & 1 & 1 & 118 & 1 & 1 & 43 & 1 & 9231 & 31987 & 15106 \\
\hline Sum & 8 & 8 & 194 & 8 & 8 & 50 & 8 & 47954 & 103136 & 91247 \\
\hline
\end{tabular}

\section{Copyrights}

Copyright for this article is retained by the author(s), with first publication rights granted to the journal.

This is an open-access article distributed under the terms and conditions of the Creative Commons Attribution license (http://creativecommons.org/licenses/by/4.0/). 